\title{
Pengolahan Citra untuk Mengetahui Tingkat Kesegaran Ikan Menggunakan Metode Transformasi Wavelet Diskrit
}

\author{
Miftahur Danar Ramadhan dan Budi Setiyono \\ Departemen Matematika, Fakultas MKSD, Institut Teknologi Sepuluh Nopember (ITS) \\ e-mail: budi@matematika.its.ac.id
}

\begin{abstract}
Abstrak-Ikan yang baik adalah ikan yang masih segar, sehingga disukai oleh konsumen. Penanganan dan sanitasi yang baik sangat diperlukan untuk tetap menjaga kesegaran ikan, makin lama berada di udara terbuka maka makin menurun kesegarannya. Pada tugas akhir ini akan dicoba untuk mengidentifikasi tingkat kesegaran ikan dengan menggunakan metode transformasi wavelet diskrit. Ikan sampel yang diuji terlebih dahulu akan disegmentasi untuk mengambil bagian insang ikan yang akan digunakan untuk mencari parameter tingkat kesegaran ikan berdasarkan warna insang. Metode yang digunakan untuk segmentasi sampel adalah metode K-Means Clustering.Pada metode segmentasi ini, citra sampel ikan dibagi menjadi beberapa bagian (cluster).Dari beberapa cluster tersebut akan dipilih bagian yang memuat insang ikan yang dijadikan obyek pengamatan. Setelah didapatkan cluster yang diinginkan citra sampel kemudian ditransformasikan menggunakan wavelet diskrit. Dari hasil transformasi tersebut akan diambil parameter yang nantinnya akan digunakan sebagai acuan untuk menentukan pembagian tingkat kesegaran ikan. Jenis ikan yang digunakan penulis sebagai data sampel adalah ikan kembung. Dari setiap data sampel ini akan dilakukan pengambil gambar sebanyak 21 sampel data training dan 9 sampel data testing. Kemudian dari setiap gambar sampel tersebut akan diidentifikasi menjadi berdasarkan 3 tinkat parameter kesegaran yaitu: ikan segar, ikan tidak segar, dan ikan busuk. Hasil dari penelitian ini, program berhasil mengidentifikasi 5 sampel ikan dengan kategori ikan 'segar' dan 4 sampel ikan dengan kategori ikan 'tidak segar'.
\end{abstract}

Kata Kunci-Ikan Segar, K-Means Clustering, Segmentasi, Transformasi Wavelet Diskrit.

\section{PENDAHULUAN}

$\mathrm{K}$ ONDISI geografi Indonesia yang merupakan negara kepulauan serta diapit oleh dua samudra yaitu samudra hindia dan samudra pasifik memungkinkan Indonesia memiliki keberagaman ikan. Selain itu keberagaman ini membuat kegiatan ekspor ikan Indonesia sangat tinggi. Menteri Perikanan dan Kelautan Susi Pudjiastuti mengatakan pada tahun 2015 produksi perikanan Indonesia mencapai 23,99 juta ton.

Ikan yang baik adalah ikan yang masih segar, sehingga disukai oleh konsumen. . Ikan segar adalah ikan yang masih mempunyai sifat sama seperti ikan hidup, baik rupa, rasa, maupun teksturnya. Ciri ikan segar berdasarkan SNI 012729.1-2006 adalah

1. Pupil mata hitam menonjol dengan kornea jernih

2. Warna insang merah tua tidak berlendir

3. Daging elastis jika ditekan serta padat

4. Lendir dipermukaan kulit jernih dan transparan
Untuk ciri ikan yang tidak segar berdasarkan hasil pegamatan adalah sebagai berikut:

1. Pupil mata terlihat mulai keruh

2. Warna insang terlihat berubah kecoklatan

3. Daging terasa lembek

4. Mulai tercium bau tidak sedap

Sedangkan ciri ikan yang sudah busuk berdasarkan hasil pengamatan antara lain:

1. Pupil mata terlihat sangat keruh

2. Warna isang berwarna coklat kehitaman

3. Daging sangat lembek dan mudah hancur.

4. Tercium bau yang sangat tidak sedap

Berdasarkan ciri-ciri ikan segar seperti diatas, kita tahu bahwa salah satunya dapat dilihat dari warna insang. Ikan yang segar dapat ditunjukkan dengan warna insang yang merah tua, ikan yang tidak segar ditunjukkan dengan warna insang kecoklatan, dan ikan yang busuk dengan warna insang yang coklat kehitaman. Suatu penelitian yang dilakukan oleh Kishore Dutta, M., Issac, A., Minhas, N., dan Sarkar, B. menggunakan pengolahan citra untuk mendeteksi tingkat kesegaran ikan. Hal ini dilakukan karena menggunakan pengolahan citra tidak akan merusak sampel ketika melakukan pengamatan. Lainnya halnya jika pengamatan yang dilakukan menggunakan bahan kimia atau lain-lain yang nantinya bisa merusak sampel.

Penelitian yang dilakukan oleh Kishore Dutta ini menggunakan metode transformasi wavelet diskrit untuk mengetahui tingkat kesegaran ikan [1]. Transformasi wavelet diskrit merupakan proses dekomposisi citra pada level dekomposisi tertentu, dimana pada setiap level dekomposisi dilakukan proses melewatkan sinyal frekuensi tinggi (highpass filter) dan frekuensi rendah (lowpass filter). Setelah itu dilakukan proses subband, dimana mengambil sample dari setengah keluaran pada masing-masing filter tersebut. Selain itu, penelitian yang dilakukan Dong Jingwei, Wei Xiaowei, Li Huile, Li Juyan menggunakan transformasi wavelet untuk pengolahan citra pada sistem radar [2]. Ada juga penelitian oleh Da-Zeng Tian; Ming-Hu Ha yang menggunakan metode transformasi wavelet pada sistem kesehatan [3]. Dari penelitian-penelitian diatas dapat disimpulkan bahwa transformasi wavelet sangat baik untuk melakukan pendeteksian citra.

\section{DASAR TEORI}

\section{A. Pengertian Citra Digital}

Citra digital adalah gambar dua dimensi yang bisa ditampilkan pada layar komputer sebagai himpunan/ diskrit nilai digital yang disebut pixel/ picture elements. Dalam 
tinjauan matematis, citra merupakan fungsi kontinu dari intensitas cahaya pada bidang dua dimensi.

Citra digital citra digital merupakan fungsi dua dimensi yang dapat dinyatakan dengan fungsi $f(x, y)$, dimana $x$ dan $y$ merupakan titik koordinat spasial. Sedangkan amplitudo dari fungsi $f$ pada sembarang koordinat $(x, y)$ merupakan nilai intensitas cahaya, yang merupakan representasi dari warna cahaya yang ada pada citra analog.

\section{B. Segmentasi Citra}

Segmentasi citra merupakan bagian dari proses pengolahan citra. Proses segmentasi citra ini lebih banyak merupakan suatu proses pra pengolahan pada sistem pengenalan objek dalam citra. Segmentasi citra (image segmentation) mempunyai arti membagi suatu citra menjadi wilayah-wilayah yang homogen berdasarkan kriteria keserupaan yang tertentu antara tingkat keabuan suatu piksel dengan tingkat keabuan piksel - piksel tetangganya, kemudian hasil dari proses segmentasi ini akan digunakan untuk proses tingkat tinggi lebih lanjut yang dapat dilakukan terhadap suatu citra, misalnya proses klasifikasi citra dan proses identifikasi objek.

Gonzalez dan Wintz menyatakan bahwa segmentasi adalah proses pembagian sebuah citra kedalam sejumlah bagian atau obyek. Segmentasi merupakan suatu bagian yang sangat penting dalam analisis citra secara otomatis, sebab pada prosedur ini obyek yang diinginkan akan disadap untuk proses selanjutnya, misalnya: pada pengenalan pola. Algoritma segmentasi didasarkan pada 2 buah karakteristik nilai derajad kecerahan citra, yaitu: discontinuity dan similarity. Pada item pertama, citra dipisahkan/dibagi atas dasar perubahan yang mencolok dari derajad kecerahannya.Aplikasi yang umum adalah untuk deteksi titik, garis, area, dan sisi citra.Pada kategori kedua, didasarkan atas thresholding, region growing, dan region spiltting and merging. Prinsip segmentasi citra bisa diterapkan untuk citra yang statis maupun dinamis.

\section{Algoritma K-Means}

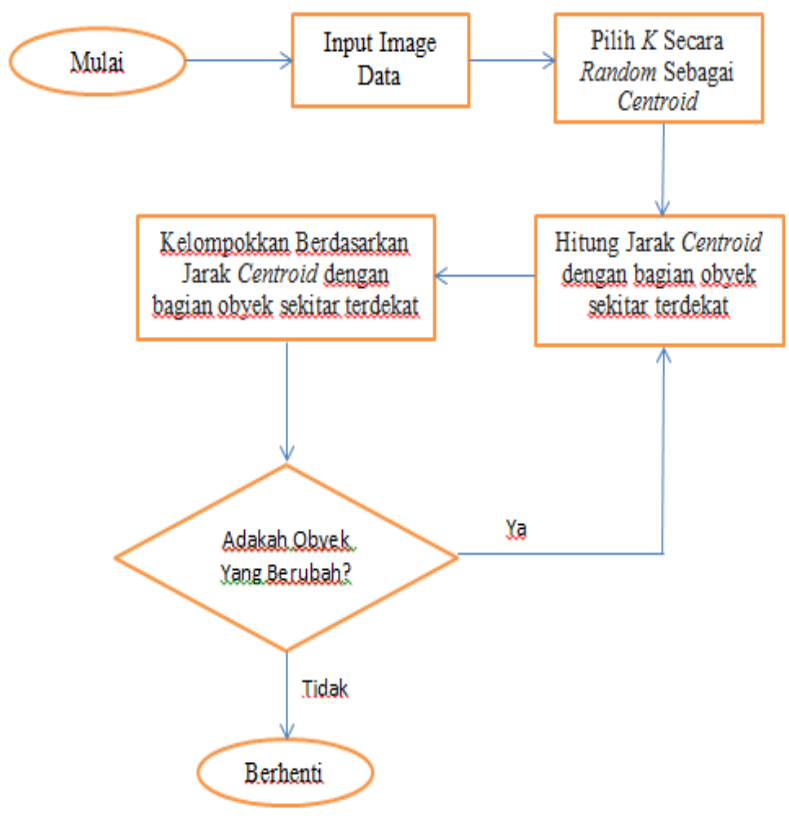

Gambar 1. Algoritma K-Means.
K-means merupakan salah satu algoritma clustering.Tujuan algoritma ini yaitu untuk membagi data menjadi beberapa kelompok.Pada algoritma ini, komputer mengelompokkan sendiri data-data yang menjadi masukannya tanpa mengetahui terlebih dulu target kelasnya.Masukan yang diterima adalah data atau objek dan $k$ buah kelompok (cluster) yang diinginkan. Algoritma ini akan mengelompokkan data atau objek ke dalam $k$ buah kelompok tersebut. Pada setiap cluster terdapat titik pusat (centroid) yang merepresentasikan cluster tersebut [4].

\section{Transformasi Wavelet Diskrit}

Transformasi wavelet memiliki pengaruh yang besar dalam bidang analisis sinyal, khususnya dalam analisis dan kompresi citra.Pada umumnya, wavelet dimanfaatkan untuk mengeksploitasi kompresi citra.

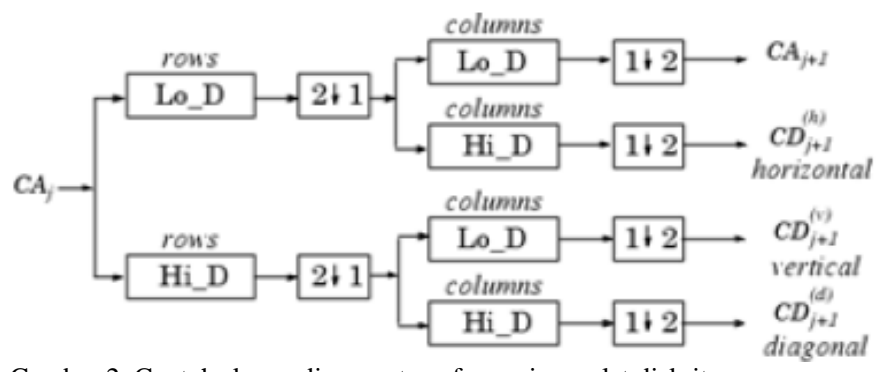

Gambar 2. Contoh skema diagram transformasi wavelet diskrit.

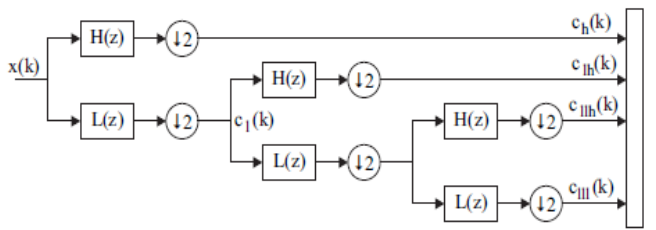

(a) analysis bank

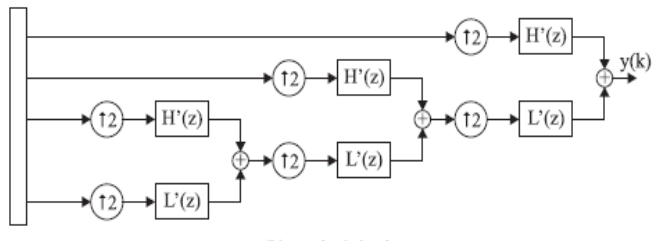

(b) synthesis bank

Gambar 3. Contoh DWT level 3.

Transformasi wavelet merupakan perbaikan dari transformasi Fourier.Pada transformasi Fourier hanya dapat menentukan frekuensi yang muncul pada suatu sinyal, namun tidak dapat menentukan kapan (dimana) frekuensi itu muncul.

Jika sinyal, fungsi penskala, dan wavelet adalah diskrit, maka persamaan deret wavelet atau sinyal diskrit disebut dengan DWT(Discrete Wavelet Transform). DWT atas suatu runtun memuat dua ekspansi deret, satu untuk approksimasi runtun dan lainnya untuk detil runtun. Definisi formal DWT atas suatu runtun $N$-titik $x[n], 0 \leq n \leq N-1$ diberikan oleh [5]

Dimana

$$
D W T\{f(t)\}=W_{\phi}\left(j_{0}, k\right)+W_{\psi}(j, k)
$$

$$
W_{\phi}\left(j_{0}, k\right)=\frac{1}{\sqrt{N}} \sum_{n=0}^{N-1} x[n] \phi_{j_{0}, k}[n]
$$




$$
W_{\psi}(j, k)=\frac{1}{\sqrt{N}} \sum_{n=0}^{N-1} x[n] \psi_{j, k}[n] \quad j \geq j_{0}
$$

Runtun $\quad x[n], 0 \leq n \leq N-1$ dapat dipulihkan dari koefisien-kkoefisien DWT $W_{\phi}$ dan $W_{\psi}$, yang diberikan oleh

$$
\begin{aligned}
x[n]=\frac{1}{\sqrt{N}} \sum_{k} W_{\phi}\left(j_{0}, k\right) \phi_{j_{0}, k}[n] & \\
& +\frac{1}{\sqrt{N}} \sum_{j=j_{0}}^{\infty} \sum_{k} W_{\psi}(j, k) \psi_{j, k}[n]
\end{aligned}
$$

\section{E. Wavelet Haar}

Haar adalah wavelet paling tua dan paling sederhana, diperkenalkan oleh Alfred Haar pada tahun 1909. Haar telah menjadi sumber ide bagi munculnya keluarga Wavelet lainnya seperti Daubechies dan lain sebagainya. Pada transformasi Haar terdapat basis fungsi $h_{k}(z)$ dimana mereka didefinisikan kontinu selama pada close interval $z \in[0,1]$ untuk $k=$ $0,1,2, \ldots, N-1$, dimana $N=2^{n}$. Didefinisikan integer $k$ adalah $k=2^{p}+q-1$, dimana $0 \leq p \leq n-1, q=0$ atau luntuk $p=0$, dan $1 \leq q \leq 2^{p}$ untuk $p \neq 0$. Sehingga basis fungsi haar adalah

Dan

$$
h_{0}(z)=h_{00}(z)=\frac{1}{\sqrt{N}}, \quad z \in[0,1]
$$

$$
\begin{aligned}
& h_{k}(z)=h_{p q}(z) \\
& =\frac{1}{\sqrt{N}}\left\{\begin{array}{c}
2^{p / 2}(q-1) / 2^{p} \leq z<(q-0.5) / 2^{p} \\
-2^{p / 2}(q-0.5) / 2^{p} \leq z<q / 2^{p} \\
0 \quad \text { untuk yg lain, } \quad z \in[0,1]
\end{array}\right.
\end{aligned}
$$

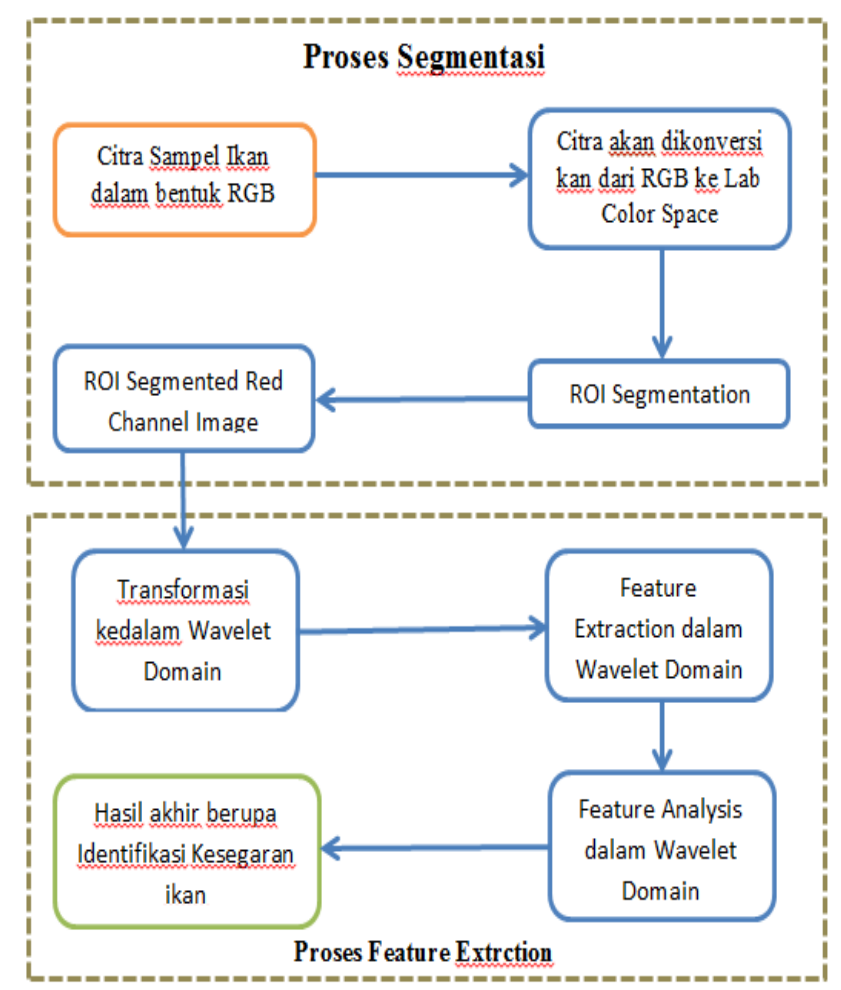

Gambar 4. Diagram alur proses program.

\section{PERANCANGAN DAN IMPLEMENTASI SISTEM}

\section{A. Pengambilan Data}

Data masukan yang akan diproses nantinya adalah berupa image ikan sebanyak 21 sampel data training dan 9 sampel data testing yang diambil mulai dari hari pertama hingga hari ke tiga. Untuk data keluaran dari sistem ini nantinya adalah berupa parameter yang akan mempresentasikan tingkat kesegaran ikan dari masing-masing sampel.

\section{B. Gambaran Sistem}

Diagram alur proses program dapat dilihat pada Gambar 4.

\section{Proses Segmentasi}

a. Konversi RGB ke Lab

Proses klustering dilakukan dengan cara mengkonversi ruang warna citra yang semula RGB menjadi ruang warna $\mathrm{L} * \mathrm{a} * \mathrm{~b}$. Warna $\mathrm{L} * \mathrm{a} * \mathrm{~b}$ dipilih karena warna $\mathrm{L} * \mathrm{a} * \mathrm{~b}$ dirancang untuk mendekati penglihatan manusia.Nilai numeric di dalam $\mathrm{L}^{*} \mathrm{a} * \mathrm{~b}$ menguraikan semua warna yang ditangkap seseorang dengan penglihatan normal.

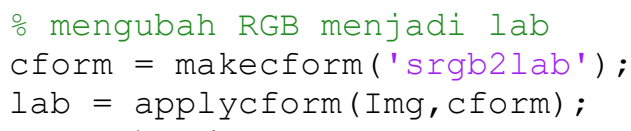

b. Proses Klustering Dengan K-Mean

Setelah melakukan konversi kedalam ruang warna $\mathrm{L}^{*} \mathrm{a} * \mathrm{~b}$, Iamge kemudian diklustering menggunakan metode $K$-Means. Source dapat ditulis sebagai berikut:

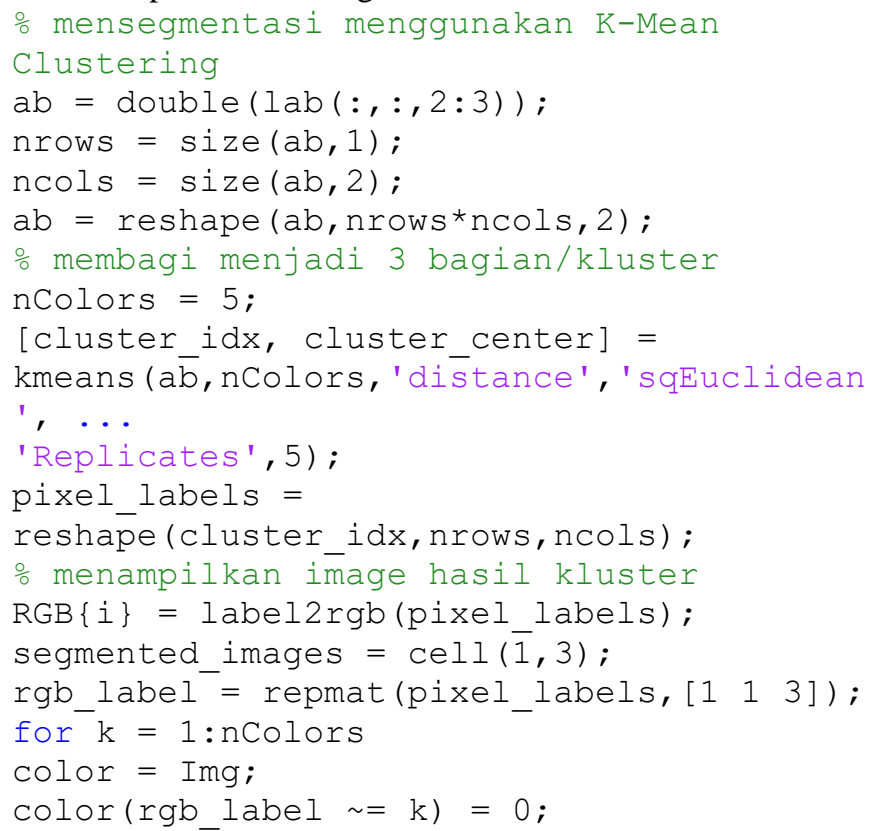




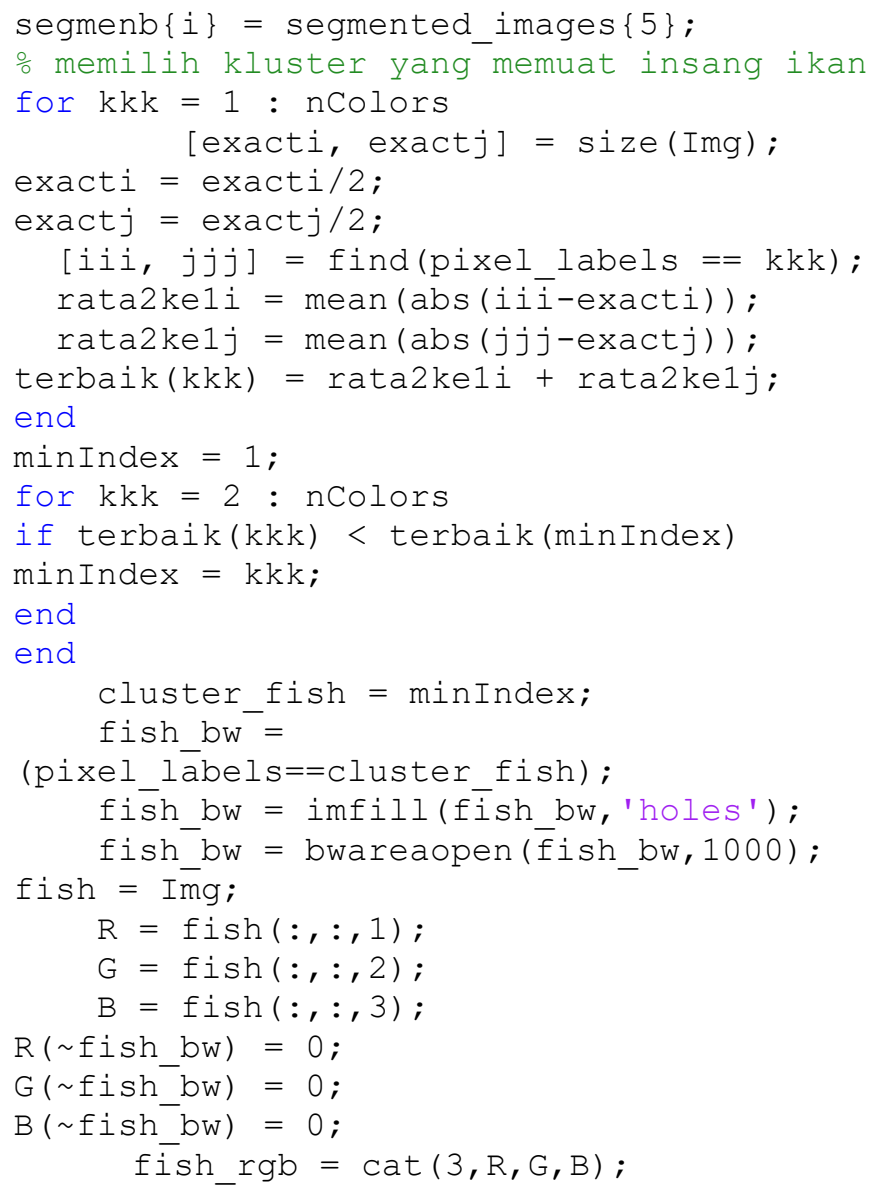

Gambar 5. Hasil Segmentasi dengan K-Means.

\section{Proses Transformasi DWT dan Ekstrasi Nilai}

a. Transformasi DWT

Sebagai contoh, misal terdapat citra dengan matriks input sebagai berikut

$$
M=\left[\begin{array}{llll}
1 & 2 & 3 & 2 \\
5 & 8 & 2 & 6 \\
2 & 5 & 8 & 9 \\
7 & 4 & 7 & 4
\end{array}\right]
$$

Akan didekomposisi dengan menggunakan Transformasi Wavelet Diskrit dengan jenis haar. Filter lowpass dan filter highpass dengan jenis haar adalah sebagai berikut :

$$
\text { Lowpass }=\left[\begin{array}{llll}
\frac{1}{\sqrt{2}} & \frac{1}{\sqrt{2}} & 0 & 0 \\
0 & 0 & \frac{1}{\sqrt{2}} & \frac{1}{\sqrt{2}}
\end{array}\right] \text { Highpass }=\left[\begin{array}{cccc}
\frac{1}{\sqrt{2}} & -\frac{1}{\sqrt{2}} & 0 & 0 \\
0 & 0 & \frac{1}{\sqrt{2}} & -\frac{1}{\sqrt{2}}
\end{array}\right]
$$

Langkah pertama adalah mengalikan filter lowpass dengan matriks $M$ terhadap baris. Untuk memudahkan perkalian terhadap baris, sebaiknya dilakukan transpose pada matriks $\mathrm{M}$, sehingga didapat :

$$
M^{\top}=\left[\begin{array}{llll}
1 & 5 & 2 & 7 \\
2 & 8 & 5 & 4 \\
3 & 2 & 8 & 7 \\
2 & 6 & 9 & 4
\end{array}\right]
$$

Kemudian dilakukan perkalian matriks $\mathrm{M}^{\mathrm{T}}$ dengan filter lowpass yang menghasilkan matriks $\mathrm{D}_{1}{ }^{\mathrm{T}}$.

$$
D_{1}^{\top}=\left[\begin{array}{cccc}
\frac{1}{\sqrt{2}} & \frac{1}{\sqrt{2}} & 0 & 0 \\
0 & 0 & \frac{1}{\sqrt{2}} & \frac{1}{\sqrt{2}}
\end{array}\right] \times\left[\begin{array}{cccc}
1 & 5 & 2 & 7 \\
2 & 8 & 5 & 4 \\
3 & 2 & 8 & 7 \\
2 & 6 & 9 & 4
\end{array}\right]=\left[\begin{array}{cccc}
2,1213 & 9,1923 & 4,9497 & 7,7781 \\
3,5355 & 5,6568 & 12,0207 & 7,7781
\end{array}\right]
$$

Untuk mengembalikan ke baris dan kolom sebenarnya, dilakukan proses transpose kembali pada matriks $\mathrm{D}_{1}{ }^{\mathrm{T}}$.

$$
D_{1}=\left[\begin{array}{cc}
2,1213 & 3,5355 \\
9,1923 & 5,6568 \\
4,9497 & 12,0207 \\
7,7781 & 7,7781
\end{array}\right]
$$

Langkah selanjutnya adalah melakukan perkalian filter lowpass dengan matriks $\mathrm{D}_{1}$ terhadap kolom. Proses tersebut menghasilkan matriks $\mathrm{D}_{2}$, sebagai berikut :

$$
D_{2}=\left[\begin{array}{cccc}
\frac{1}{\sqrt{2}} & \frac{1}{\sqrt{2}} & 0 & 0 \\
0 & 0 & \frac{1}{\sqrt{2}} & \frac{1}{\sqrt{2}}
\end{array}\right] \times\left[\begin{array}{cc}
2,1213 & 3,5355 \\
9,1923 & 5,6568 \\
4,9497 & 12,0207 \\
7,7781 & 7,7781
\end{array}\right]=\left[\begin{array}{ll}
8 & 6,5 \\
9 & 14
\end{array}\right]
$$

Matriks $\mathrm{D}_{2}$ ini yang disebut dengan koeficien aproksimasi (LL). Untuk mencari nilai HL, LH dan HH, sama seperti langkah diatas, namun dilakukan dengan mengalikan filter lowpass terhadap baris dan filter highpass terhadap kolom untuk HL, mengalikan filter highpass terhadap baris dan filter lowpass terhadap kolom untuk LH dan mengalikan filter highpass terhadap baris dan kolom untuk $\mathrm{HH}$.

b. Ekstrasi Nilai

Setelah proses transformasi kedalam DWT nantinya akan diambil (extract) nilai koefisien data hasil transformasi tersebut. Nilai tersebut akan digunakan untuk mencari nilai Mean dan Standart Deviation.

$$
\operatorname{Mean}(\sigma)=\frac{\sum_{i} \sum_{j} I(i, j)}{\mathrm{M} \times \mathbf{N}}
$$

$$
\text { Standard Deviation }=\sqrt{\frac{\{I(i, j)-\sigma\}^{2}}{\mathrm{M} \times \mathrm{N}}}
$$

Dimana I adalah image citra insang ikan dan $\mathrm{M}$ x N adalah sizeimage dari insang ikan.Mean dan Standart Deviationakan menjadi acuan dalam menentukan tingkat kesegaran ikan. Untuk ikan segar (FR1) akan dilihat berdasarkan jarak nilai Mean dan Standart Deviation tertiggi pada hari pertama (FL0) dengan nilai Mean dan Standart Deviation terendah pada hari pertama (FL1). Untuk ikan tidak segar (FR2) akan dilihat berdasarkan jarak nilai Mean dan Standart Deviation teredah pada hari pertama (FL1) dengan nilai Mean dan Standart Deviation terendah pada hari ketiga (FL2). Dan untuk ikan busuk (FR3) akan dilihat berdasarkan jarak nilai Mean dan Standart Deviation teredah pada hari ketiga (FL2) dengan nilai Mean dan Standart Deviation terendah pada hari kelima (FL3).

1. $F R 1=$ Jika $(F L 0 \geq$ Mean $\geq$ FL1) dan (FL0 $\geq$ Standart Deviasi $\geq$ FL1)

2. FR2 $=$ Jika $(F L 1 \geq$ Mean $\geq$ FL2) dan (FL1 $\geq$ Standart Deviasi $\geq$ FL2) 
3. FR3 $=$ Jika (FL2 $\geq$ Mean $\geq$ FL3) dan (FL2 $\geq$ Standart Deviasi $\geq$ FL3)

Dimana,

FR1 = Kategori ikan segar

FR2 $=$ Kategori ikan tidak segar

FR3 = Kategori ikan busuk

FLO = Nilai tertinggi dari semua sampel pada parameter statistik di hari pertama

FL1 = Nilai terendah dari semua sampel pada parameter statistic di hari pertama

FL2 = Nilai terendah dari semua sampel pada parameter statistic di hari kedua

FL3 = Nilai terendah dari semua sampel pada parameter statistic di hari ketiga.

\section{ANALISIS DAN PEMBAHASAN}

\section{A. Data Uji Coba}

Uji coba pada sistem identifikasi kesegaran ikan ini akan menggunakan 21 imagetraining sampel dan 9 imagetesting sampel yang terdiri dari 7 training sampel ikan yang diambil pada hari 1, 7 training sampel ikan yang diambil pada hari 2, 7 training sampel ikan yang diambil pada hari 3. 3 testing sampel ikan yang diambil pada hari 1, 3 testing sampel ikan yang diambil pada hari 2, 3 testing sampel ikan yang diambil pada hari 3. (Tabel 1)

\section{B. Pengujian Ekstrasi Nilai}

Image sampel yang telah ditransformasikan menggunakan DWT, kemudian dilakukan ekstrasi nilai untuk mendapatkan nilai mean dan standart devition. Nilai dari mean dan standart deviation dari setiap sampel dapat dilihat pada Tabel 2:

Tabel 1.

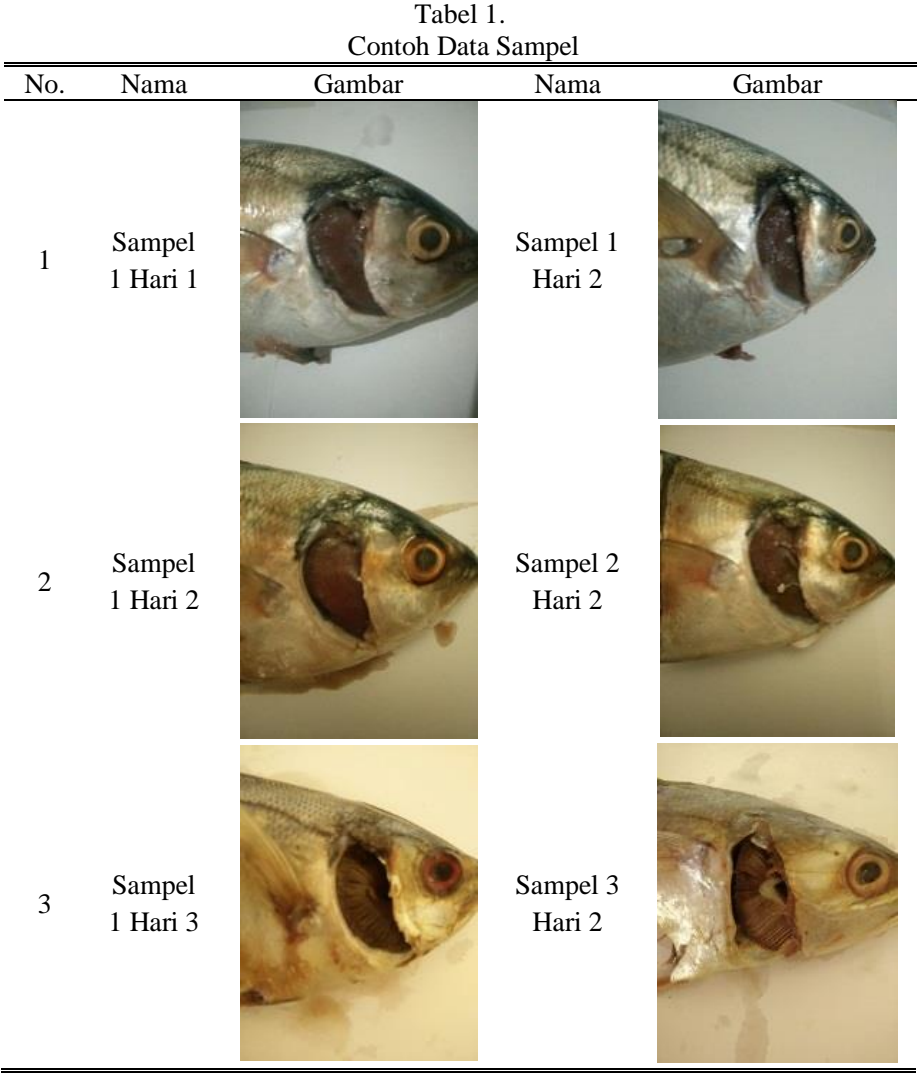

Tabel 2.

Nilai Mean dan Standar deviasi data training

\begin{tabular}{ccccc}
\hline \hline No. & Nama & Waktu & Mean & Standart Deviation \\
\hline 1 & & Sampel 1 & 0.61 & 25 \\
2 & & Sampel 2 & -0.86 & 32 \\
3 & & Sampel 3 & 0.32 & 47 \\
4 & Hari 1 & Sampel 4 & -0.27 & 19 \\
5 & & Sampel 5 & -0.16 & 17 \\
6 & & Sampel 6 & 0.22 & 45 \\
7 & & Sampel 7 & 0.24 & 13 \\
8 & & Sampel 1 & 0.35 & 15 \\
9 & & Sampel 2 & 0.37 & 21 \\
10 & & Sampel 3 & 0.47 & 19 \\
11 & Hari 2 & Sampel 4 & 0.19 & 13 \\
12 & & Sampel 5 & -0.25 & 16 \\
13 & & Sampel 6 & 0.32 & 25 \\
14 & & Sampel 7 & 0.09 & 17 \\
15 & & Sampel 1 & -0.16 & 19 \\
16 & & Sampel 2 & 0.06 & 13 \\
17 & & Sampel 3 & -0.78 & 29 \\
18 & Hari 3 & Sampel 4 & -1.24 & 49 \\
19 & & Sampel 5 & -0.42 & 49 \\
20 & & Sampel 6 & -0.05 & 37 \\
21 & & Sampel 7 & 0.16 & 13 \\
\hline \hline
\end{tabular}

Tabel 3.

Nilai Mean dan Standar deviasi data testing

\begin{tabular}{ccccc}
\hline \hline No. & Nama & Waktu & Mean & Standart Deviation \\
\hline 1 & & Sampel 1 & 0.14 & 29 \\
2 & Hari 1 & Sampel 2 & -0.40 & 24 \\
3 & & Sampel 3 & 1.54 & 53 \\
4 & & Sampel 1 & -0.31 & 18 \\
5 & Hari 2 & Sampel 2 & 0.51 & 22 \\
6 & & Sampel 3 & 0.01 & 20 \\
7 & & Sampel 1 & -0.42 & 17 \\
8 & Hari 3 & Sampel 2 & -2.14 & 45 \\
9 & & Sampel 3 & 0.36 & 40 \\
\hline \hline
\end{tabular}

Tabel 4.

Nilai Max dan Min dari Mean

\begin{tabular}{ccc}
\hline \hline No. & Nama & Mean \\
\hline 1. & Nilai Max Mean hari 1 & 0.61 \\
2. & Nilai Min Mean hari 1 & -0.86 \\
3. & Nilai Min Mean hari 2 & -0.25 \\
4. & Nilai Min Mean hari 3 & -0.24 \\
\hline \multicolumn{3}{c}{ Tabel 5. } \\
\multicolumn{3}{c}{ Nilai Max dan Min dari Sytandart Deviation } \\
\hline \hline No. & Nama & Standart Deviation \\
\hline 1. & Nilai Max Standart Deviation hari 1 & 47.03 \\
2. & Nilai Min Standart Deviation hari 1 & 13.32 \\
3. & Nilai Min Standart Deviation hari 2 & 13.07 \\
4. & Nilai Min Standart Deviation hari 3 & 12.89 \\
\hline \hline
\end{tabular}

Dari Tabel 5 dan Tabel 6 diperoleh hasil akhir pengujian identifikasi sampel ikan adalah sebagai berikut:

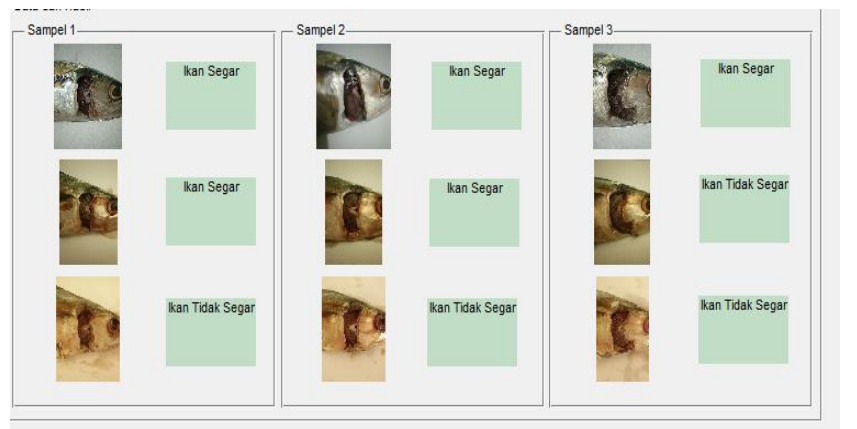

Gambar 6. Hasil Identifikasi Ikan. 


\section{KESIMPULAN DAN SARAN}

Berdasarkan analisa dari hasil identifikasi tingkat kesegaran ikan dengan metode wavelet ini, penulis dapat menarik kesimpulan sebagai berikut :

1. Tugas akhir ini telah berhasil melakukan identifikasi kesegaran ikan dengan menggunakan metode wavelet dengan tahapan segmentasi Image ikan dengan metode $K$ Means Clustering, kemudian mentranformasikan kedalam DWT, dan kemudian mengambil parameter identifikasi dari hasil transformasi tersebut.

2. Pada tugas akhir ini sistem berhasil mengidentifikasi image pada sampel 1 sampai 5 sebagai ikan dengan kategori ikan yang masih 'segar' dan sampel 6 sampai 9 sebagai ikan dengan kategori ikan yang 'tidak segar'

Berdasarkan hasil yang dicapai pada penelitian ini, ada beberapa hal yang penulis sarankan untuk pengembangan selanjutnya yaitu:

1. Pada penelitian ini penulis hanya menggunakan metode DWT dengan filter Haar. Penulis menyarankan untuk menggunakan Wavelet Symlet, Wavelet Daubechies, atau Wavelet Coifflet sebagai perbandingan.

2. Pada tugas akhir ini penulis menjadikan insang ikan sebagai obyek penelitian untuk menentukan tingkat kesegaran ikan. Penulis menyarankan untuk menggunakan obyek lain seperti warna mata ikan, ataupun tingkat kekenyalan daging ikan.
3. Hasil segmentasi image masih memuat beberapa noise yang bisa mempengaruhi nilai parameter yang digunakan untuk identifikasi ikan. Diharapkan penelitian berikutnya untuk menambahkan penghilangan noise pada hasil segmentasi image.

4. Menambahkan sampel data ikan diperlukan untuk memberikan hasil parameter identifikasi yang lebih akurat.

\section{DAFTAR PUSTAKA}

[1] M. K. Dutta, A. Issac, N. Minhas, and B. Sarkar, "Image processing based method to assess fish quality and freshness," J. Food Eng., vol. 177, pp. 50-58, May 2016.

[2] D. Jingwei, W. Xiaowei, L. Huile, and L. Juyan, "Processing method of marine radar image based on wavelet transform," in 2013 IEEE 11th International Conference on Electronic Measurement \& Instruments, 2013, pp. 704-707.

[3] Da-Zeng Tian and Ming-Hu Ha, "Applications of wavelet transform in medical image processing," in Proceedings of 2004 International Conference on Machine Learning and Cybernetics (IEEE Cat. No.04EX826), vol. 4, pp. 1816-1821.

[4] M. Khalid, N. Pal, and K. Arora, "Clustering of Image Data Using K-Means and Fuzzy K-Means,” Int. J. Adv. Comput. Sci. Appl., vol. 5, no. 7, 2014.

[5] H. Olkkonen and J. T., "Discrete Wavelet Transform Algorithms for Multi-Scale Analysis of Biomedical Signals," in Discrete Wavelet Transforms - Algorithms and Applications, InTech, 2011. 